\title{
Newly Discovered Tuff in the Lower Shaximiao Formation in Yunyang, Chongqing, Southwestern China and Its Constraint on the Burial Age of the Yunyang Dinosaur Fauna
}

\section{Yuxuan Zhou}

Institute of Sedimentary Geology, Chengdu University of Technology, Chengdu 610059

Wenguang Yang ( $\sim$ yangwg1018@gmail.com )

Institute of Sedimentary Geology, Chengdu University of Technology, Chengdu 610059

Hui Dai

No. 208 Hydrogeological and Engineering Geological Team, Chongqing Bureau of Geological and Mineral Resource Exploration and Development, Chongqing 400700

\section{Hongliang Zhang}

College of Earth Sciences, Chengdu University of Technology,Chengdu 610059

\section{Xufeng Hu}

No. 208 Hydrogeological and Engineering Geological Team, Chongqing Bureau of Geological and Mineral Resource Exploration and Development, Chongqing 400700

\section{Deliang Li}

Chongqing Institute of Geological Survey, Chongqing 401122

\section{Haidong Yu}

No. 208 Hydrogeological and Engineering Geological Team, Chongqing Bureau of Geological and Mineral Resource Exploration and Development, Chongqing 400700

\section{Lidong Zhu}

Institute of Sedimentary Geology, Chengdu University of Technology, Chengdu 610059

Chao Tan

No. 208 Hydrogeological and Engineering Geological Team, Chongqing Bureau of Geological and Mineral Resource Exploration and Development, Chongqing 400700

Ning Li

No. 208 Hydrogeological and Engineering Geological Team, Chongqing Bureau of Geological and Mineral Resource Exploration and Development, Chongqing 400700

\section{Research Article}

Keywords: Sichuan Basin, Shaximiao Formation, Yunyang Dinosaur Fauna, Tuff, Burial Age 
Posted Date: June 28th, 2021

DOl: https://doi.org/10.21203/rs.3.rs-624972/v1

License: (c) (i) This work is licensed under a Creative Commons Attribution 4.0 International License. Read Full License 
1 Newly Discovered Tuff in the Lower Shaximiao Formation in

2 Yunyang, Chongqing, Southwestern China and Its Constraint on the

3 Burial Age of the Yunyang Dinosaur Fauna

4

5 Yuxuan Zhou ${ }^{1,2}$, Wenguang Yang ${ }^{1 *}$, Hui Dai ${ }^{2}$, Hongliang Zhang ${ }^{3}$, Xufeng $\mathrm{Hu}^{2}$,

Deliang $\mathrm{Li}^{4}$, Haidong $\mathrm{Yu}^{2}$, Lidong $\mathrm{Zhu}^{1}$, Chao $\mathrm{Tan}^{2}$, Ning $\mathrm{Li}^{2}$

$8{ }^{1}$ Institute of Sedimentary Geology, Chengdu University of Technology, Chengdu

$9 \quad 610059$, China

2 Chongqing Laboratory of Geoheritage Protection and Research, No. 208

Hydrogeological and Engineering Geological Team, Chongqing Bureau of Geological and Mineral Resource Exploration and Development, Chongqing 400700, China

${ }^{3}$ College of Earth Sciences, Chengdu University of Technology, Chengdu 610059,

China

${ }^{4}$ Chongqing Institute of Geological Survey, Chongqing 401122, China 


\section{Abstract}

The Shaximiao Formation is one of the important Mesozoic burial horizons of dinosaur fossils in the Sichuan Basin. Although a large number of research results on the stratigraphic age of the Shaximiao Formation have been published, the age and division of the Shaximiao Formation are still controversial. To a certain extent, this affects the precise constraints on the burial age of the dinosaur fauna in Yunyang, Chongqing. In this study, the newly discovered tuff intercalation in the Lower Shaximiao Formation in Pu'an Township, Yunyang County, Chongqing City, was taken as the research object, and its lithology and formation age were determined using thin section identification, X-ray diffraction (XRD), scanning electron microscopy (SEM), and U-Pb zircon dating. The field observations and thin section microscopic characteristics of the rocks reveal that the clay rock intercalation has a typical sedimentary tuff structure, which is altered lithic tuff. The SEM imaging and XRD results indicate that it has a typical tuff mineral composition. The U-Pb zircon dating shows that the weighted average age of the newly discovered tuff is $174.8 \pm$ 2.4 Ma, and the burial age of the dinosaur fossils is estimated to be $174.7 \pm 2.4 \mathrm{Ma}$ based on the sedimentation rate and the thickness of the stratum.

Key words: Sichuan Basin; Shaximiao Formation; Yunyang Dinosaur Fauna; Tuff;

\section{Burial Age}




\section{Introducation}

Since 2016, a large number of dinosaur fossils have been found in the Xintiangou Formation and the Lower Shaximiao Formation in the village of Laojun, Pu'an Township, Yunyang County, Chongqing City (Li et al., 2019; Tan et al., 2019, 2020; Dai et al., 2020a, 2020b; Hao et al., 2017), which further expands the distribution range of the Jurassic dinosaur fossils in the Sichuan Basin, China. Previous studies of the stratigraphic ages of the Xintiangou and Shaximiao formations in the Sichuan Basin have conducted a great deal of work, and the opinions on the stratigraphic age of Xintiangou Formation are quite consistent, that is, the Xintiangou Formation was deposited in the Middle Jurassic (Xie et al., 1982; Compilation Group of Terrestrial Mesozoic Stratigraphy and Paleontology in Sichuan Basin, 1982). However, there the age and division of the Shaximiao Formation are still somewhat controversial. The Shaximiao Formation is divided into two lithologic sections, i.e., the Upper Shaximiao Formation and the Lower Shaximiao Formation (Zhang, 2017), the naming of which is more in line with the international stratigraphic nomenclature standard (Yang, 2014; Zhang, 2017).The Lower Shaximiao Formation is generally considered to have been deposited in the Middle Jurassic (Wang et al., 2010), and some paleontologists believe that the Upper Shaximiao Formation was also deposited in the Middle Jurassic (Compilation Group of Terrestrial Mesozoic Stratigraphy and Paleontology in Sichuan Basin, 1982; Sun, 1996; Wang et al., 2010). However, some vertebrate paleontologists believe that it was deposited in the Upper Jurassic (Zhao et al., 1965; Dong, 1980; Wang et al., 
2003). Recently, Huang summarized previous data and proposed that the Lower Shaximiao Formation can be divided into the Middle-Upper Jurassic Batongian-Oxfordsian, and the Upper Shaximiao Formation can be divided into the Oxfordian-Qinmolian (Huang, 2019). There are also several differences in the relatively precise geological ages reported for the Shaximiao Formation, including $167 \mathrm{Ma}, 172 \mathrm{Ma}$ (Electron Spin Resonance) (Zong et al., 1997), 172-167 Ma, 178$169 \mathrm{Ma}$ (ESR) (Gou et al., 2000), $163 \pm 3 \mathrm{Ma}$ (the youngest U-Pb zircon age for the detrital rocks) (Li et al., 2010), $160 \pm 4 \mathrm{Ma}$ (weighted average age of the detrital rocks) (Luo et al., 2014), $158 \pm 7 \mathrm{Ma}$ (weighted average age of the detrital rocks) (Qian et al., 2016), and $159 \pm 2 \mathrm{Ma}$ (U-Pb weighted average age of the detrital rocks) (Wang et al., 2018). These results indicate that the existing data cannot effectively constrain the sedimentary age of the Shaximiao Formation, nor can it provide precise burial age constraints for the Yunyang dinosaur fauna found in the Lower Shaximiao Formation in Yunyang, Chongqing, southwestern China.

Due to the lack of large-scale volcanic activity in the Sichuan Basin, there are few reports of tuff. Huang concluded that the claystone of the P/T Boundary in the Zhongliangshan area, Chongqing, was the product of the alteration of volcanic material (Huang, 1992; Zhang et al., 2005). According to Zhang et al., felsic volcanic ash is present in the clay rocks of Middle Jurassic Upper Shaximiao Formation in Wanzhou, and its source may be related to the Tethys volcanic activity (Zhang et al., 2005). Ran et al. conducted U-Pb isotopic dating on the volcanic intercalations in the Xujiahe Formation in western Sichuan and obtained a weighted 
average age of $214.7 \pm 1.6 \mathrm{Ma}$ (Ran et al., 2016). Due to the regional characteristics of the distribution and evolution of terrestrial organisms, it is difficult to compare these fossils with the European marine stage standard fossils, and the isotopic chronology lacks reliable dating materials to accurately restrict the age. In this study, $\mathrm{U}-\mathrm{Pb}$ zircon isotopic dating was carried out on newly discovered tuff intercalations in the strata underlying the Lower Shaximiao Formation in Yunyang, Chongqing. The ages of the Lower Shaximiao Formation and the burial age of the Yunyang dinosaur fauna were determined.

\section{Materials and methods}

The tuff intercalation found in this study is located in the Lower Shaximiao Formation, Pu'an Township, Yunyang County, Chongqing City, and it is about $21 \mathrm{~m}$ below the dinosaur burial horizon and $210 \mathrm{~m}$ above the bottom of the Shaximiao Formation $\left(30^{\circ} 50^{\prime} 42.23^{\prime \prime} \mathrm{N} ; 108^{\circ} 55^{\prime} 22.70^{\prime \prime} \mathrm{E}\right)$ (Fig. 1). The tuff intercalation is mainly clay, with a thickness of about $8 \mathrm{~cm}$, and is exposed in the clastic rocks. The rock is grayish green and soft (Fig. 2). 

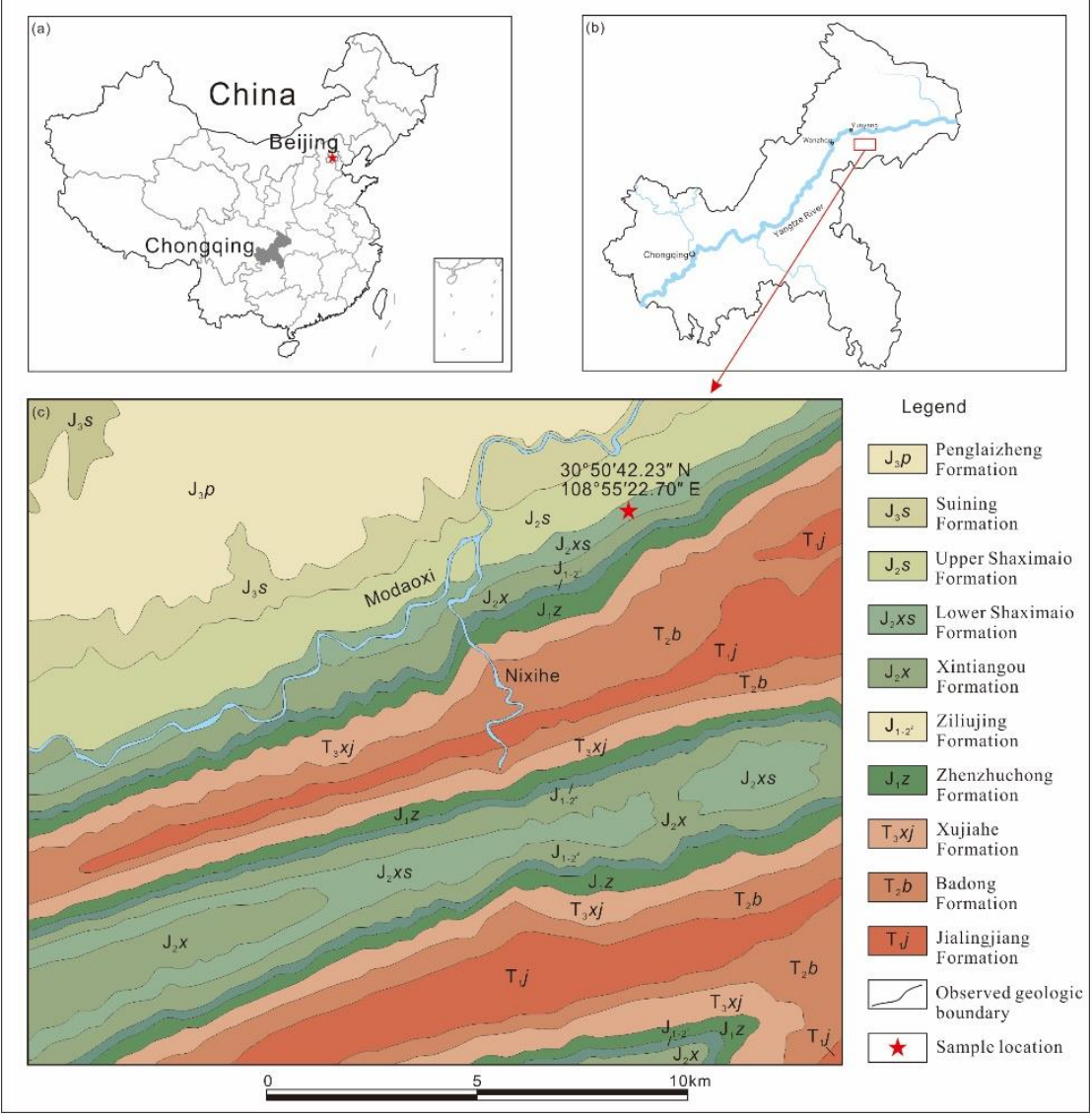

Fig.1. Geographic and geologic maps showing the location of the study area. (a) The geographic position of Chongqing city. (b) The geographic position of the study area. (c) Geologic map of the study area.

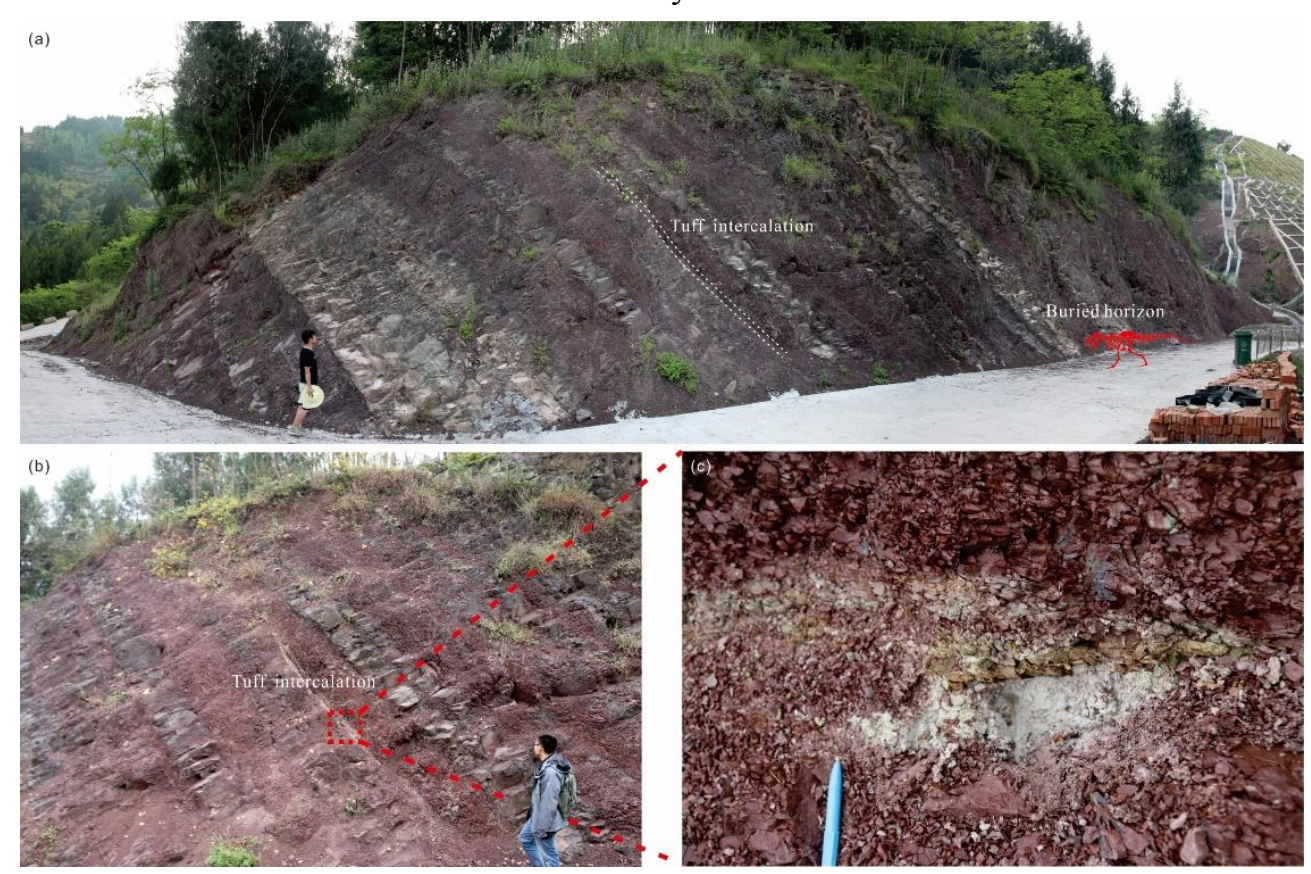

Fig.2. Field characteristics of the tuff interlayer in the Lower Shaximiao Formation, Yunyang, Chongqing, China. (a) Partial outcrop of the Lower Shaximiao Formation. (b) The tuff interlayer within the Lower Shaximiao Formation. (c) The field characteristic of the tuff. 
of tests and analysis on the samples. The most ideal block samples HP02-32 were

111 selected for thin section preparation, and then pulverized tuff samples from the

112 fraction $<2 \mu \mathrm{m}$ were analyzed to determine their total mineral compositions using X-ray diffraction (XRD) at the Chengdu University of Technology, meanwhile the mineral composition of the tuff was analyzed using scanning electron microscopy 115 (SEM). experimental results, in this study, relatively fresh and pure tuff samples were selected for the $\mathrm{U}-\mathrm{Pb}$ zircon dating. In addition, in order to ensure the randomness of the experiment, the HP02-32 samples were divided into four samples and were sent to the same laboratory for testing. The zircon sorting, target preparation, and testing were conducted by Beijing Zircon Navigation Technology Co., Ltd. (China). The sample and data processing used methods were previously described by Zhang et al.

123 (Zhang et al., 2019).

\section{Results}

\subsection{Petrography}

Under the microscope, the rock exhibits an obvious crystal chip tuff structure,

127 which is composed of crystal chips, tuff grade glass chips, and volcanic dust. Melted harbor like quartz (Figs. 3a, b), rock debris (Figs. 3c, d), explosive crystal chips (Fig. 3e), arc-shaped semi plastic glass chips, and tearing mica (Fig. 3f) were observed. 

are too small to be further resolved.
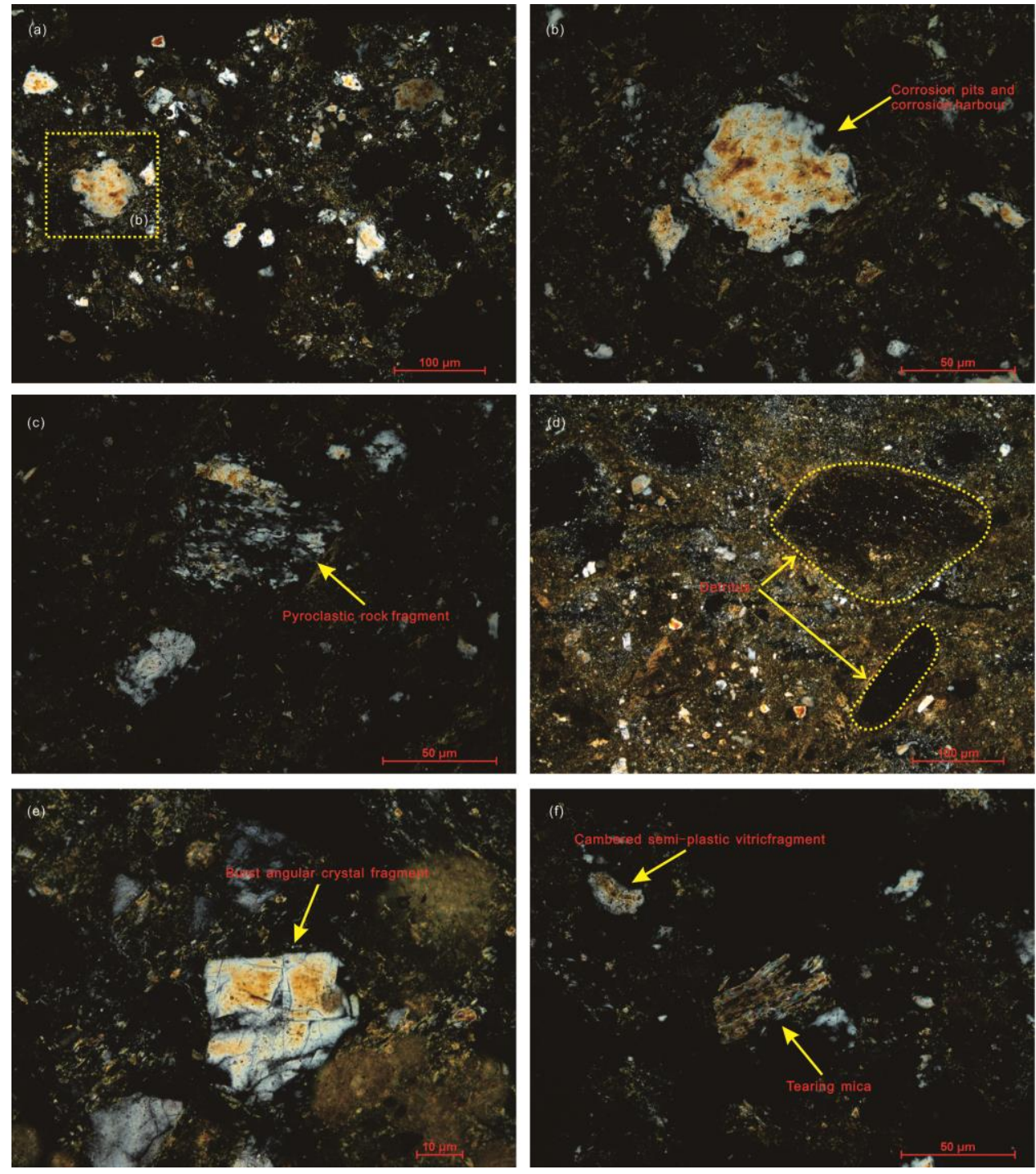

Fig.3. Microphotograph (+) of the tuff in the Lower Shaximiao Formation, Yungyang,

Chongqing, China. (a) Macroscopic features of quartz. (b) Corrosion pits and corrosion harbour of quartz. (c) Pyroclastic rock fragment. (d) Rock detritus. (e) Burst angular crystal fragment.

(f) Cambered semi- piastic vitric fragment and tearing mica.

The microscopic characteristics of the samples reveal that they have undergone a certain degree of alteration. Moreover, they are different from the typical lithic crystalline tuff studied by other scholars (Xu et al., 2019). However, they are somewhat similar to the characteristics of sedimentary tuff (Tang, 2020). Therefore, 
143 in this study, this tuff is defined as an altered clastic tuff.

144 3.2. X-ray diffraction (XRD) analysis

The mineral compositions obtained from the XRD analyses are presented in

146 Table 1. Representative XRD diagrams are shown in Fig. 4. The tuff samples are

147 dominated by clay minerals (58-62\%), quartz (21-22\%), and plagioclase (17-19\%).

148 It is worth noting that the XRD results show that bentonite exists in the samples.

149 The volcanic ash produced during a volcanic eruption can be transported and 150 distributed at a distance from the crater by wind, water, and other media (Ruddiman

151 et al., 1972; Brown et al., 2012; Qiu et al., 2014). In sedimentary environments, 152 volcanic ash (tephra) usually alters to clay minerals (e.g., smectite and illite) during 153 diagenesis (Liao et al., 2016; Hong et al., 2017, 2019), and these devitrified volcanic 154 ash fall beds are usually referred to as K-bentonites (Hong et al., 2019). Table 1 Mineral compositions from the XRD analysis results

\begin{tabular}{l|l}
\hline Sample & Mineral compositions (wt\%) \\
\hline HP02-32-1 & clay minerals (illite/smectite) 62; quartz 21; plagioclase 17 \\
HP02-32-2 & clay minerals (illite/smectite) 58; quartz 22; plagioclase 19 \\
\hline
\end{tabular}




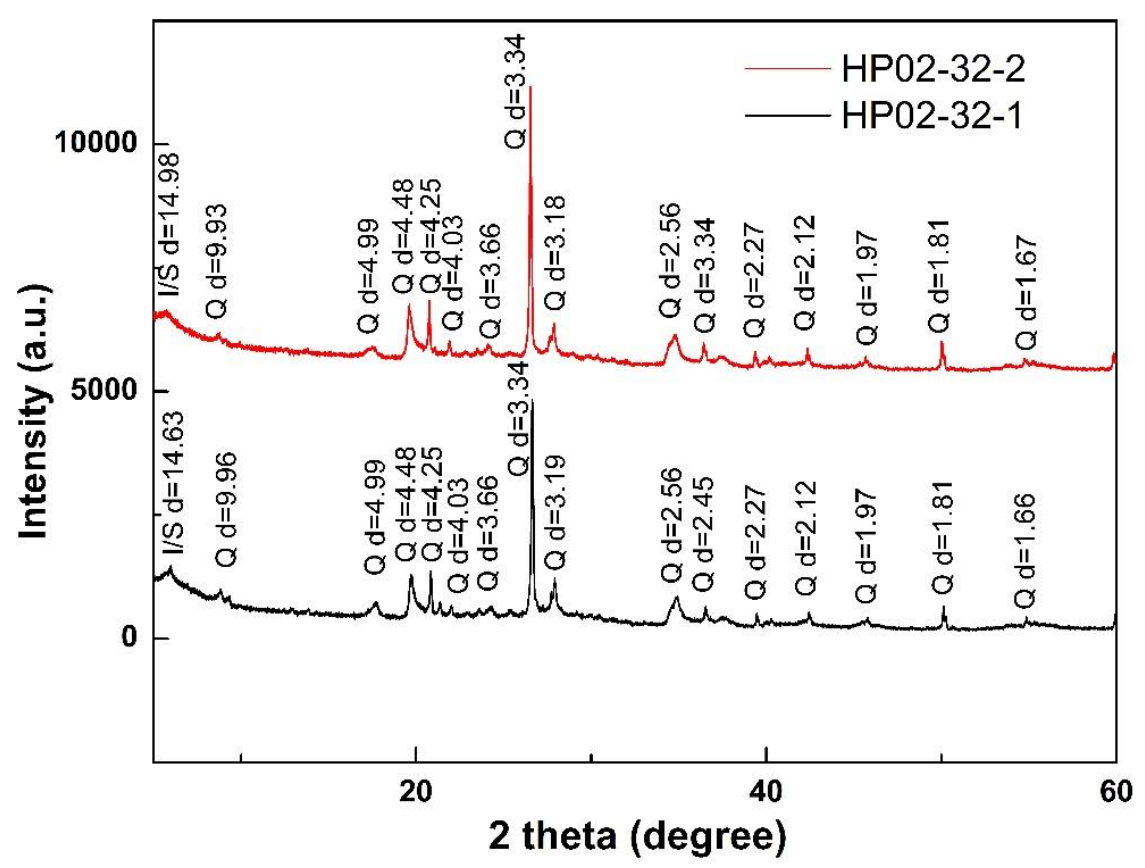

Fig. 4. Representative XRD patterns of the Lower Shaximiao Formation tuff. I/S: illite/smectite; Q: quartz; and Pl: plagioclase.

\subsection{Scanning electron microscopy analysis}

Under the scanning electron microscope, lamellar illite (Fig. 5a) and kaolinite (Fig. 5b) with an incomplete crystal morphology were observed. The boundary between the feldspar and matrix in the thin section is clear, and fine lines similar to cleavage or bicrystals were observed at the fracture surfaces. The fine grains are transverse grains corresponding to the long axis direction (Fig. 5c) and prismatic laumontite (Fig. 5d). The results of the scanning electron microscopy and X-ray diffraction are basically consistent, and the samples may be intermediate felsic tuff. 

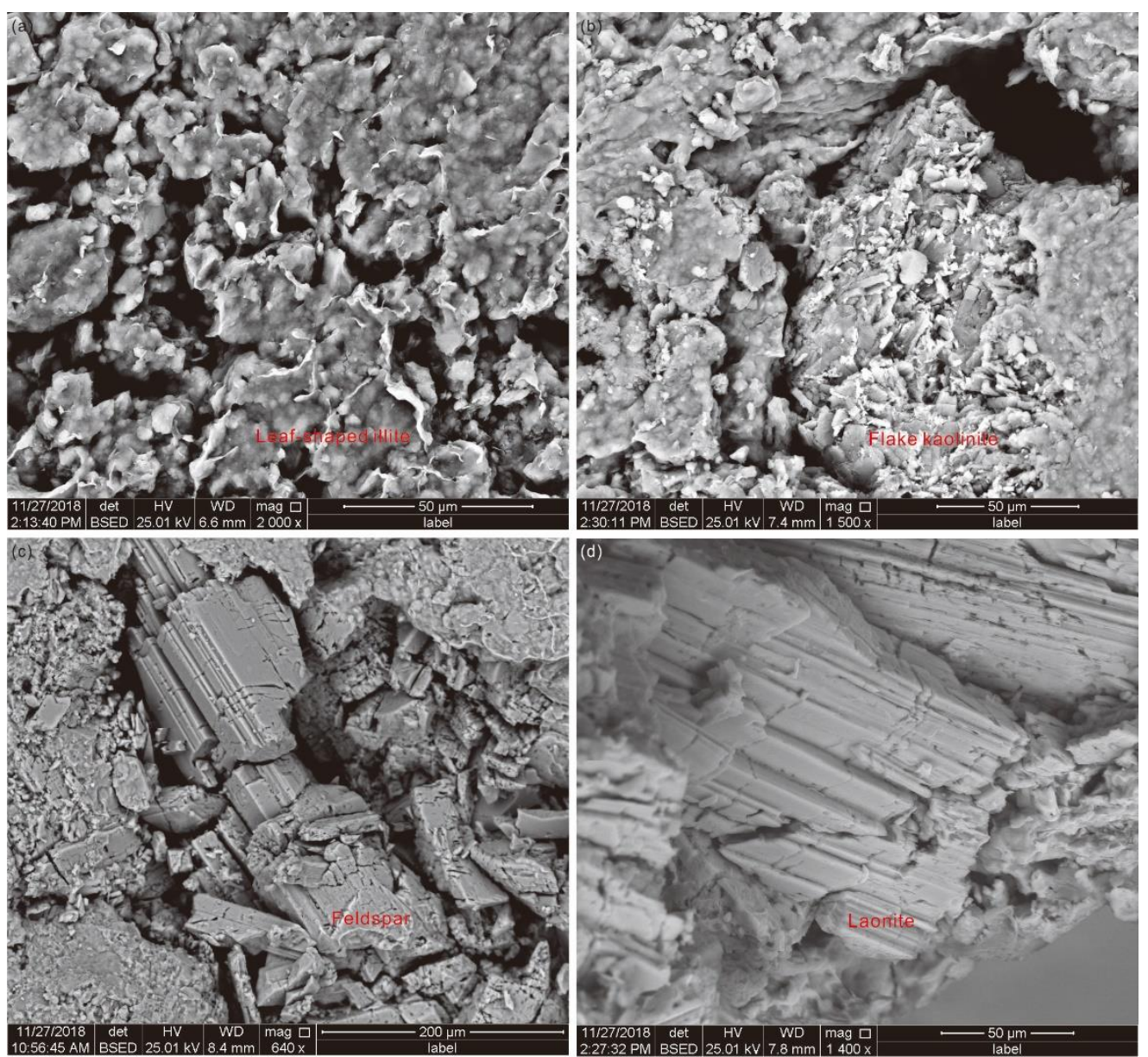

Fig. 5. Scanning electron microscope (SEM) imaging characteristics of the Lower Shaximiao

Formation tuff in Yunyang, Chongqing (All of the images are backscattered electron images,

BSED.).

\subsection{U-Pb zircon geochronology}

The cathodoluminescence (CL) images of the zircons (Fig. 6) show that most of

the zircons exhibit relatively consistent morphological characteristics, i.e., complete zircon grains, straight edges, a high degree of automorphism, and mostly long columnar shapes, which are obviously different from those of general detrital zircons.

The zircons studied were 90-180 $\mu \mathrm{m}$ long, 35-90 $\mu \mathrm{m}$ wide, and have length to width ratios of 2:1 to $3: 1$. Most of the zircons had obvious magmatic oscillatory zonation structures with uniform and small widths. The $\mathrm{Th} / \mathrm{U}$ ratios of the zircons ranged from 0.35 to 1.3 , with an average of 0.60 , indicating that the zircons are of magmatic 
181

182

183

184

185

186

187

188

189

190

191

mixed into the volcanic ash during diagenesis.

origin (Andersen, 2002; Belousova, 2002).

A total of 44 zircons were selected for the U-Pb isotopic dating. After deducting the lower concordance zircon age data, 34 sets of data (concordance $>90 \%$ ) were used. The data shows that the minimum age of the zircons was $167 \mathrm{Ma}$, and the maximum age was $1851 \mathrm{Ma}$, with two peak ages of $\sim 170 \mathrm{Ma}$ and $\sim 230 \mathrm{Ma}$. The dominant peak age was $\sim 170 \mathrm{Ma}$ (sample number 16) (Figs. 6, 7). The weighted average age was $174.8 \pm 2.4 \mathrm{Ma}(\mathrm{N}=16, \mathrm{MSWD}=5.0)$. According to the latest geological time scale, the age of the tuff is near the boundary between the Early Jurassic and the Middle Jurassic. The U-Pb zircon ages exhibit a distribution pattern consistent with detrital zircon ages, which may be because some clastic rocks were

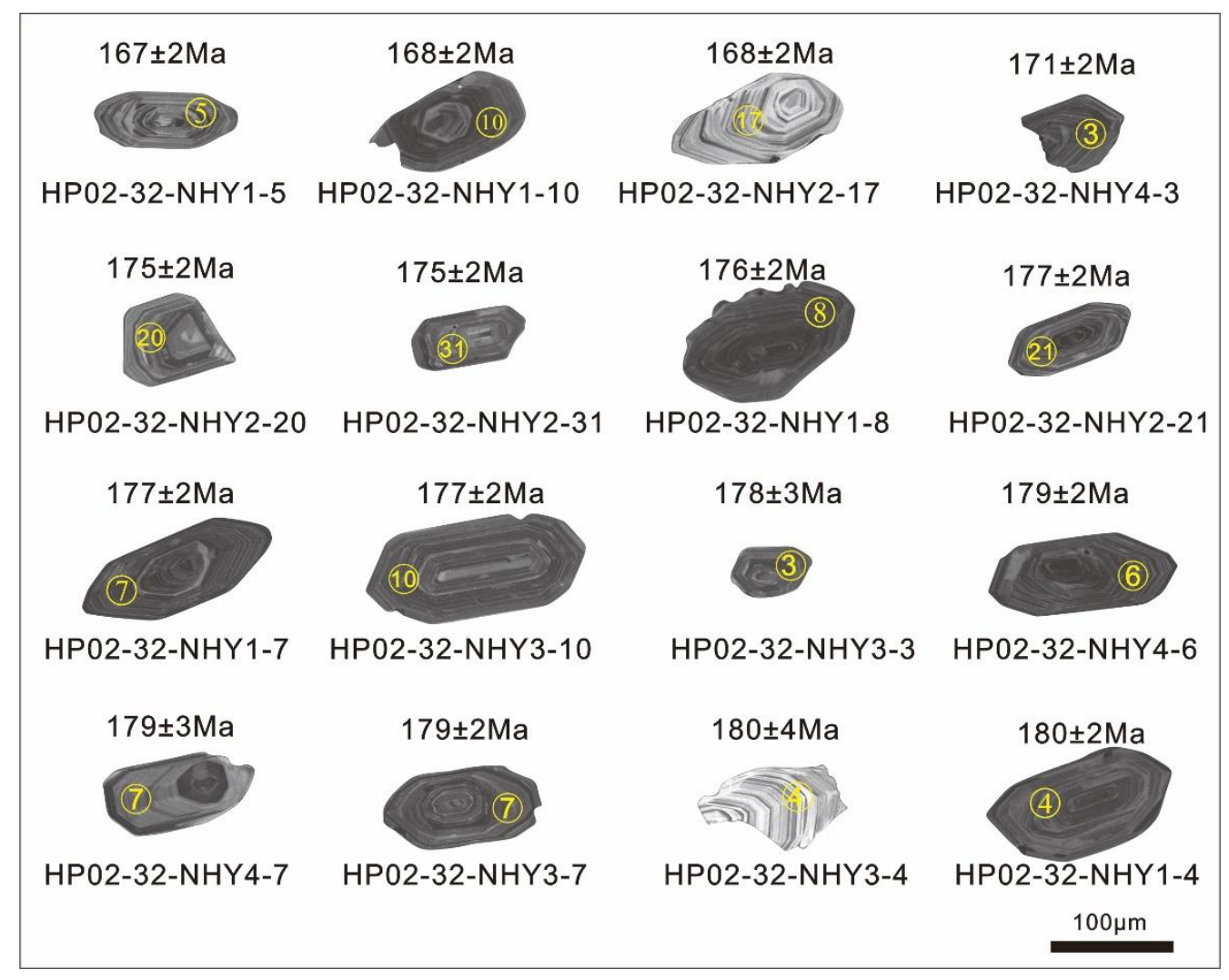

193 Fig. 6. CL image of zircons from the tuff in Lower Shaximiao Formation, Yungyang, Chongqing 
195

196

197

198

199

200

201

202

203

204

205

206

207

208

209

210

211

212
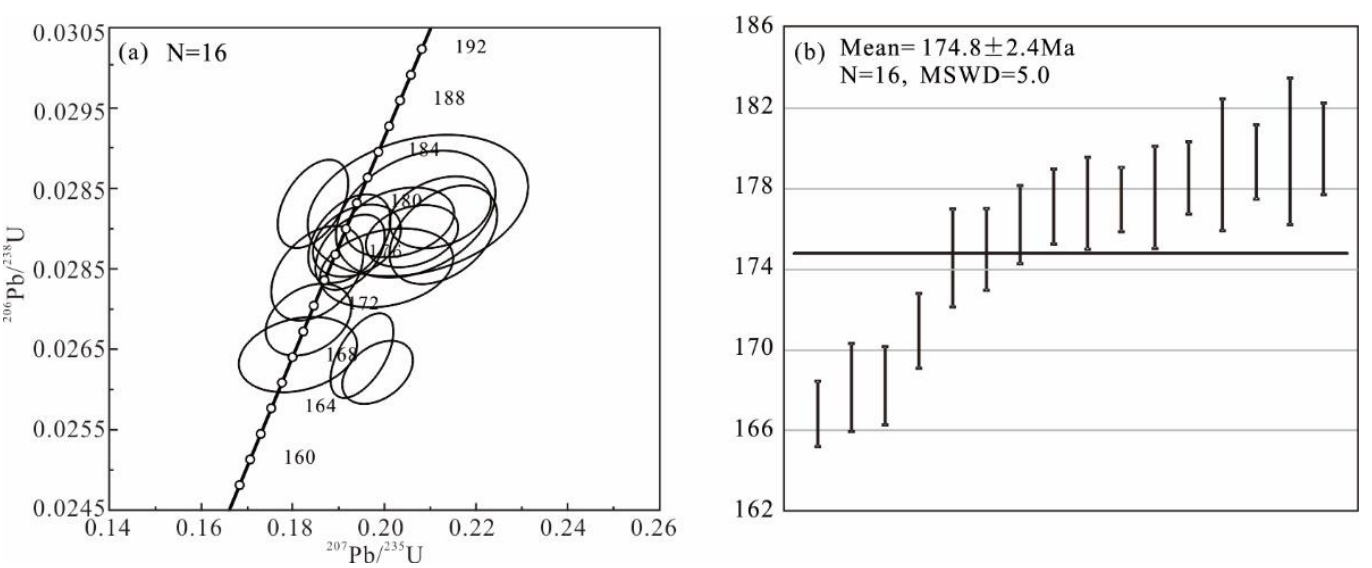

Fig. 7. Zircon U-Pb concordant age of the tuff in the Lower Shaximiao Formation, Yunyang, Chongqing, China.

\section{Discussion}

The Shaximiao Formation is one of the important burial horizons for Mesozoic dinosaur fossils in the Sichuan Basin. Previous discussions of the age of the dinosaur fossil burial horizon have mainly been based on regional lithologic correlations (Hou et al., 1976), dinosaur fossil species (Zhao,1965), and invertebrate fossil assemblage (Wang et al., 2005), additionally, some scholars have tried to constrain the fossil burial age through detrital zircon $\mathrm{U}-\mathrm{Pb}$ dating of the underlying strata (Wang et al., 2018). In this study, we also attempted to use the sporopollen assemblage and $\mathrm{U}-\mathrm{Pb}$ zircon dating of the clastic rocks to constrain the burial age of the fossils. Spore and pollen samples were collected from the Shaximiao Formation in Pu'an Township, Yunyang, Chongqing. The lithology of the samples was purplish red silty mudstone. Only two fern spores, Deltoidospora and Baculatisporites, were identified in the 20 sporopollen samples. The results show that it is difficult to determine the burial age of the dinosaur fossils based on the sporopollen assemblages in the study area due to the lack of pollen in the Lower Shaximiao 
Formation. U-Pb zircon dating of clastic rock sample (Sample HP02-54, discussed in another paper) from beneath the fossil burial horizon in the Lower Shaximiao Formation in the study area shows that the samples have five age ranges of $\sim 160$ 180Ma, 240-260 Ma, 420-450 Ma, 1730-1900 Ma, and 2400-2600 Ma. The six youngest zircons were selected to calculate the weighted average age of $169 \pm 0.65$ $\mathrm{Ma}(\mathrm{N}=6, \mathrm{MSWD}=2.05)$. This age is younger than that of the tuff.

The U-Pb age of the zircons from the tuff effectively constrain the burial age of dinosaur fossils (Luo et al., 1999; Jiang et al., 2010; Wang et al., 2020). Therefore, the discovery of this sedimentary tuff interlayer in the study area provides new material and ideas for effectively constraining the age of the Shaximiao Formation and for determining the burial age of the Yunyang dinosaur fauna. Therefore, we believe that the U-Pb zircon age of the sedimentary tuff can limit the burial age of the dinosaur fossils. The age of the Upper Shaximiao Formation is about $169 \pm 0.68$ Ma (Sample HP02-361, discussed in another paper), and the thickness between the two layers is about $1050 \mathrm{~m}$. The calculated sedimentation rate is about $210 \mathrm{~m} / \mathrm{Ma}$. The bottom of the Lower Shaximiao Formation is about $210 \mathrm{~m}$ below the tuff interlayer. The burial horizon of the Yunyang dinosaur fauna is about $21 \mathrm{~m}$ above the tuff interlayer. It is inferred that the lower age limit of the Shaximiao Formation in Yunyang, Chongqing, is $175.8 \pm 2.4 \mathrm{Ma}$, and the burial age of the dinosaur fossils is $174.7 \pm 2.4 \mathrm{Ma}$. 


\section{Conclusions}

236 Based on the petrographic, SEM, XRD, and U-Pb zircon dating analyses of the 237 newly discovered tuff in the Lower Shaximiao Formation, Yunyang, Chongqing, it is 238 concluded that the tuff is a lithic crystalline tuff, with an average weighted $\mathrm{U}-\mathrm{Pb}$ 239 zircon age of $174.8 \pm 2.4 \mathrm{Ma}$, which is near the boundary between the Lower 240 Jurassic and the Middle Jurassic. Based on the deposition rate and thickness, the 241 burial age of the dinosaur fossils is $174.7 \pm 2.4$ Ma.

\section{List of abbreviations}

244 ESR Electron Spin Resonance

245 XRD X-ray Diffraction

SEM Scanning Electron Microscopy

247

248

249

250

251

252

253

\section{References}

1. Andersen, T.. Correction of common lead in U-Pb analyses that do not report ${ }^{204} \mathrm{~Pb}$. Chemical Geology 192, 59-79(2002).

2. Belousova, E.A., Griffin, W.L., O'Reilly, S.Y. \& Fisher, N.I. Igneous zircon: trace element composition as an indicator of source rock type. Contributions to Mineralogy and Petrology 143, $602-622(2002)$

3. Brown, R.J., Bonadonna, C. \& Durant, A.J. A review of volcanic ash aggregation. Physics and Chemistry of the Earth, Parts A/B/C 45-46, 65-78(2012).

4. Compilation Group of Terrestrial Mesozoic Stratigraphy and Paleontology in Sichuan Basin. Continental Mesozoic Stratigraphy and Paleontology in Sichuan Basin of China. (Peoples Publishing House of Sichuan, Chengdu, 1982).

5. Dai, H., Benson, R., Hu, X.F., Ma, Q.Y., Tan, C., Li, N., Xiao, M., Hu, H.Q., Zhou, Y.X., Wei, Z.Y., Zhang, F., Jiang, S., Li, D.L., Peng, G.Z., Yu, Y.L. \& Xu, X. A new possible megalosauroid 
theropod from the Middle Jurassic Xintiangou Formation of Chongqing, People's Republic of China and its implication for early tetanuran evolution. Scientific Reports 10, 1-16(2020a).

6. Dai, H., Ma, Q.Y., Hu, X.F., Zhou, Y.X., Tan, C. \& Li, N. A New Dinosaur Fauna is Discovered in Yunyang, Chongqing, China. Acta Geologica Sinica (English Edition) 94, 216-217(2020b).

7. Dong, Z.M. Dinosaur fauna and its horizon, China(in Chinese). Journal of Stratigraphy 4, 256-263(1980).

8. Gou, Z.H., Zhao, B. \& Wu. S. Jurassic system of Dayi, Chongzhou, Wenchuan and Dujiangyan, Sichuan(in Chinese, with English abstract). Journal of Chengdu University of Technology 27,

10. Hong, H.L., Fang, Q., Wang, C.W., Churchman, G.J, Zhao, L.L., Gong, N.N. \& Yin, K.

9. Hao, Z.G., Fei, H.C., Hao, Q.Q. \& Liu, L. A Large Dinosaur Assemblage has been Discovered in Pu'an, Yunyang County, Chongqing, China. Acta Geologica Sinica (English Edition) 91, 1487-1488(2017).

Clay mineralogy of altered tephra beds and facies correlation between the Permian-Triassic boundary stratigraphic sets, Guizhou, south China. Applied Clay Science 143, 10-21(2017).

11. Hong, H.L., Zhao, L.L., Fang, Q., J.Algeo, T., Wang, C.W., Yu, J.X., Gong, N.N., Yin, K. \& Ji, K.P. Volcanic sources and diagenetic alteration of Permian-Triassic boundary K-bentonites in Guizhou Province, South China. Palaeogeography Palaeoclimatology Palaeoecology 519, 141-153(2019).

12. Hou, L.H., Zhou, S.W. \& Cao, Y.S. New discovery of Sauropods in Sichuan (in Chinese). Vertebrata PalAsiatica 14(3), 160-165+211(1976).

13. Huang, D.Y. Jurassic integrative stratigraphy and timescale of China. Science China Earth Science 62, 223-255(2019).

14. Huang, S.J. Clay minerals in clay rocks near $\mathrm{P} / \mathrm{T}$ boundary from guangyuan and Chongqing, Sichuan (in Chinese, with English abstract). Journal of Chengdu University of Technology 19, 66-73(1992).

15. Huang, S.J. Microspherulitic and clastic mineral in the clay rock near the Permian-Triassic interface of Zhongliangshan Mountain, Chongqing(in Chinese, with English abstract). Acta Sedimentalogica Sinica 11, 105-113(1993).

16. Jiang, X.J., Liu, Y.Q., Ji, S.A., Zhang, W., Zhang, X.L., Xu, L., Jia, S.H., Lv, C.X. \& Li, M. 
SHRIMP U-Pb Dating of Zircons from Tuffs of the Lower Cretaceous Jiudian Formation in Ruyang Basin, Western Henan, and Constraint on Stratigraphic Sequences of Dinosaur Fossils-Bearing (in Chinese, with English abstract). Geological Review 56, 161-173(2010).

17. Li, N., Dai, H., Tan, C., Hu, X.F., Wei, Z.Y., Lin, Y., Wei, G.B., Li, D.L., Meng, L., Hao, B.Q., 
Chronology of the pyroclastic layer from Xujiahe Formation in the western Sichuan Basin and its geological significance(in Chinese, with English abstract). Journal of Chengdu University of Technology (Science \& Technology Edition) 43, 727-736(2016).

25. Ruddiman, W.F., Glover, L.K. Vertical mixing of ice-rafted volcanic ash in North Atlantic sediments. Geological Society of America Bulletin 83, 2817-2835(1972).

26. Su, D.Z. A new semionotid Fish from the Jurassic of Sichuan basin and its biostratigraphic significance(in Chinese, with English summary). Vertebrata PalAsiatica 34, 91-101+166(1996).

27. Tan, C., Dai, H., He, J.J., Zhang, F., Hu, X.F., Yu, H.D., Li, N., Wei, G.B., Peng, G.Z. \& Ye, Y. Discovery of Omeisaurus (Dinosauria: Sauropoda) in the Middle Jurassic Shaximiao Formation of Yunyang, Chongqing, China. Vertebrata PalAsiatica 57, 105-116(2019).

28. Tan, C., Xiao, M., Dai, H., Hu, X.F., Li, N., Ma, Q.Y., Wei, Z.Y., Yu, H.D., Xiong C. \& Peng, G.Z. A new species of Omeisaurus (Dinosauria: Sauropoda) from the Middle Jurassic of Yunyang, Chongqing, China. Historical Biology, DOI: 10.1080/08912963.2020.1743286(2020).

29. Tang, M.Y. LA-ICP-MS zircon U-Pb ages of andesic tuffite from Bayan Har Group, Heishi North Lake area, west Kunlun, Xinjiang(in Chinese, with English abstract). Geological Bulletin of China 39, 642-646(2020).

30. Wang, J., Ye, Y., Pei, R., Tian, Y.M., Feng, C.Q., Zheng, D.R. \& Chang, S.C. Age of Jurassic basal sauropods in Sichuan, China: A reappraisal of basal sauropod evolution. GSA Bulletin 130, 1493-1500(2018).

31. Wang, M., Zhong, Y.T., He, B., W.Denyszyn, S., Wang, J. \& Xu, Y.G. Geochronology and geochemistry of the fossil-flora-bearing Wuda Tuff in North China Craton and its tectonic implications. Lithos 364-365, 105485(2020).

32. Wang, Q.W., Kan, Z.Z., Zhu, B., Liang, B. \& Yang, H.S. Bivalve Fauna in the Middle Jurassic Upper Shaximiao Formation as Burying Place of Dinosaurs, in Guangyuan, Sichuan (in Chinese, with English abstract). Acta Geologica Sichuan 25, 1-3(2005).

33. Wang, Y.D., Fu, .H., Xie, .P., Huang, .S., Li, K., Li, G., Liu Z.S., Yu, J.X., Pan, Y.H., Tian, N. \& Jiang, Z.K. The terrestrial Triassic and Jurassic Systems in the Sichuan Basin, China. (China University of Science and Technology Press, Hefei, 2010).

34. Wang, Z.X., Li, K. \& Liu, J. Mamenchisaurus from Upper Jurassic of Jianyang, Sichuan(in Chinese, with English abstract). Journal of Chengdu University of Technology (Science \& 
Technology Edition) 30, 485-490(2003).

351

352

353

35. Xie, Z.X., Xia Z.S. General situation of Sichuan stratigraphic work in the past sixty years (in Chinese). Acta Geologica Sichuan 3(1), 29-35(1982).

36. Xu, Q.W., Wang, P., Wang, Z.Q., Wang, C.M., Zheng, Y. \& Fang, J. LA-ICP-MS Zircon U-Pb Ages, Geochemical Characteristics of the Dashizhai Formation Tuffs in Hexigten Banner, Inner Mongolia and Their Tectonic Significance(in Chinese, with English abstract). Geological Review $65,119-149(2019)$

37. Yang, C.Y. The phylogenetic evolution of Mamenchisauridae(in Chinese, with English abstract), Chengdu University of Technology, (2014).

38. Zhang, C., Ma, C.Q., She, Z.B. \& Yin, K.L. Volcanic ash in the clay rocks from Upper Shaximiao Formation of Middle Jurassic, Northeast of Sichuan Basin: evidence from Petrolog, Mineralogy and Geochemistry(in Chinese, with English abstract). Geological Journal of China University 11, 415-424(2005).

39. Zhang, H.L., Yang, W.G., Zhu, L.D., Lu, Z.Y., Su, X. \& Li C.Z. Zircon U-Pb age, geochemical characteristics and geological significance of highly differentiated S-Type granites in the South Lhasa Block(in Chinese, with English abstract). Mineralogy and Petrology 39, 52-62(2019).

40. Zhang, X.S. Study of Stratigraphic Classification and the Sedimentary System of Early-Middle Jurassic in Bijie Northwest Area of Guizhou Province (in Chinese, with English abstract), Chengdu University of Technology, (2017).

41. Zhao, X.J. Jurassic dinosaurs found in Sichuan(in Chinese). Geological Review 23, $341-342+344(1965)$

42. Zong, H., Shi, H. 1997.The Jurassic System of Dujiangyan, Pengzhou and Shifang, Sichuan(in Chinese, with English abstract). Journal of Stratigraphy 21, 192-202(1997).

\section{Acknowledgments}

We are grateful to GuangBiao Wei and JianJun He for organizing the field geological survey and to Haiqian Hu, Zhiyou Lu, Yuanjun Mai, Yu Liu, Xin Su, Xiaolong Chen, Yao Zhong, Yu Zhou, JunGe Qin, and YuanYin Jia for participating 
378 in the field work. This study was supported by the Project of Dinosaur Fossil

379 Protection and Research of the Chongqing Planning and Natural Resources Bureau 380 (No. KJ-2018035), the National Natural Science Foundation of China (No. 381 41972118), and the Sixth Funding Program for the Development of Young and 382 Middle-aged Teachers of the Chengdu University of Technology (No. 383 JXGG201719).

\section{Author contributions}

Yuxuan Zhou lead the project, organize the paper. Wenguang Yang is in charge of writing and refining the paper. Hongliang Zhang is responsible for all plots, initial analysis and some writing. All other co-authors make equal contributions by 389 wording discussions, comments and reading proof.

\section{Availability of data and materials}

391 All data and materials generated or analyzed during this study are included in this 392 published paper

\section{Competing interests}

394 The authors declare that they have no known competing financial interests or personal relationships that could have appeared to influence the work reported in this paper. 